\title{
Krystian Ka£UŻa
}

https://orcid.org/oooo-0002-7605-8132

Uniwersytet Opolski

\section{Rola Tradycji w Kościele. Między "archeologizmem" a „entuzjazmem"}

\section{Abstract \\ The Role of Tradition in the Church: Evolution or only Repetition? The Historical and Theological Contexts}

The article is an attempt to answer the question about the relation between tradition and the development of theological cognition. The church from the first centuries was aware that allegiance to the council tenets exceeds a technical repetition of council's formulas. It is clear that a belief in dogma assumes openness to both the past and the future.

In the article two approaches to tradition are criticized: archeological and enthusiastic. The first one is linked with attempt to end the possibility of adding to a developing tradition further at any point in history; the second one is a result of conviction that currents form of doctrine and church are exactly what is wanted by God.

In reference to K. Rahner, J. Ratzinger and W. Kasper the typological-sacramental meaning of the tradition was proposed. It lets us - basing on the statements of the Vatican II - overcome a progressivist hermeneutic of rupture and go toward a hermeneutic of continuity and to the real reform of the church. In other words, it means that the process of reception and realization of Jesus' teaching and of the history of Christianity lives on and every epoch, every culture and every generation has a task to deepen and to better understand all revelation given to us by Christ. It must be done with a sensitivity to the historical, cultural and religious contexts of every period of history including the present.

\section{KeYwords}

tradition, hermeneutic of continuity, hermeneutic of rupture 
Słowo „tradycja” nie ma dziś najlepszej prasy. Kojarzy się ze stagnacją, skostnieniem oraz zdystansowaniem wobec wszelkich prób zmian rzeczywistości. W powszechnej świadomości społecznej tradycja jest antytezą postępu. Tradycjonalista to ktoś, kto uznał, że wszelki postęp jest upadkiem, degradacją, odejściem od prawdy, która z zasady jest trwała i niezmienna. Podobny stosunek do tradycji obserwujemy w Kościele. Jej krytycy wskazują na konieczność otwarcia się na świat oraz podjęcie wyzwań, jakie niesie ze sobą zmieniający się kontekst społeczno-kulturowy. Jeśli Kościól chce zachować realny wpływ na rozwój społeczności, jeśli pragnie współkształtować współczesny świat, musi na nowo przemyśleć swoje nauczanie (zwłaszcza w kwestiach etycznych i społecznych) oraz dostosować je do wymogów, jakie stawia przed nim współczesna cywilizacja. Rozwój nauki i technologii wymusza wręcz rozwój doktryny Kościoła, która w wielu punktach nie nadąża za naukowym obrazem świata, kreowanym przez nowoczesne przyrodoznawstwo. Obrońcy tradycji, uważający się zwykle za strażników ortodoksji i jedynych prawdziwych apologetów Kościoła, operują dokładnie odwrotną perspektywą. Ich zdaniem chrześcijaństwo musi zachować dystans wobec świata, gdyż inaczej rozpłynie się w falach relatywizmu, które jak wody potopu zalewają współczesną cywilizację Zachodu. To nie świat jest miarą Ewangelii, ale Ewangelia jest boską miarą świata. Jej usunięcie doprowadzi nie tylko do upadku chrześcijaństwa, ale także do rozpadu zbudowanej na nim cywilizacji. Wyczuwamy, że przedstawiciele obydwu stanowisk mają swoje racje, jak i że racji nie mają. Istota sporu dotyka bezpośrednio rozumienia Tradycji oraz jej roli w życiu i nauczaniu Kościoła. Czym jest Tradycja? Czy tylko mechanicznym powtarzaniem obecnych od samego początku niezmiennych prawd wary? Jaki jest stosunek Tradycji do objawienia Bożego? Jak się ma formuła językowa (dogmat wiary) do wyrażonej w niej prawdy wiary? Czy może istnieć autentyczny rozwój poznania teologicznego, zgodnie $z$ Tradycją? Jeśli tak, to co jest jego wewnętrzną zasadą i gdzie szukać kryteriów jego normatywności? Próbując odpowiedzieć na te i podobne pytania, należy zacząć od ustalenia rozumienia samego pojęcia Tradycji w Kościele i teologii. 


\section{Teologiczne pojęcie Tradycji}

Samo słowo „tradycja” (gr. paradosis, łac. traditio) wskazuje na proces trwania i przekazu pewnej rzeczywistości ${ }^{1}$. W dzisiejszej teologii katolickiej przyjmuje się, że właściwe pojęcie Tradycji należy tworzyć w ścisłym odniesieniu do jej źródła, którym jest Boże objawienie. Objawienie, rozumiane jako zbawcze samoudzielanie się Boga człowiekowi, dokonało się w historii i dociera do nas w ludzkim słowie apostolskiego kerygmatu oraz wyznania wiary. $Z$ tego też powodu Tradycję należy uznać za podstawową zasadę poznania teologicznego, gdyż dzięki niej - i tylko dzięki niej - mamy dostęp do pierwotnego i normatywnego centrum wiary, jakim jest autentyczne objawienie się Boga-Agape w swoim Synu, Jezusie Chrystusie.

\section{NORMATYWNOŚć TRADYCjI}

Jako teologiczna zasada poznania, Tradycja apostolska i kościelna dość wcześnie stała się normą określającą ortodoksję i integralność chrześcijańskiego wyznania wiary, zwłaszcza w kontekście polemiki z gnostycyzmem oraz w trakcie wielkich kontrowersji trynitarnych, chrystologicznych i związanych z teologią łaski. W tej perspektywie Tradycja nie jest po prostu narracyjnym przekazywaniem takich czy innych idei i doświadczeń religijnych, lecz stanowi poświadczające i autorytatywne przekazywanie Objawienia przez Apostołów i ich następców, które nieprzerwanie trwa w Kościele i domaga się okazania posłuszeństwa, tzn. osobistej odpowiedzi wiary².

Z drugiej strony dzieje wczesnego Kościoła pokazują, że dogmaty zdefiniowane na wielkich soborach nie były kresem, lecz raczej punktem wyjścia interpretacji Objawienia w Kościele. Zwłaszcza w okresie posoborowym dokonywał się długi proces recepcji - często w atmosferze

I W złożonym fenomenie tradycji można wyróżnić: podmiot przekazujący (tradycja aktywna: transmissio) oraz podmiot odbierający (tradycja pasywna: traditum). Ze względu na przekazywane treści (przedmiot tradycji) rozróżnia się tradycję realną (zwyczaje, kult itd.) oraz werbalną (doktryna, pismo itd.). Por. J. Cuda, Wiarygodna antropologia. Hermeneutyczny zarys teologii fundamentalnej, Katowice 2002, s. 54 .

2 G. L. Müller, Katholische Dogmatik. Für Studium und Praxis der Theologie, Freiburg im Br. 19962, s. 69. 
sporów, zmagań i konfliktów. W czasie tego procesu wyłaniał się dopiero trwały sens danego orzeczenia oraz następowała stopniowa akceptacja ze strony wspólnoty wierzących. W konsekwencji Kościół dość wcześnie uświadomił sobie, że wierność względem orzeczeń soborowych jest czymś więcej niż mechanicznym powtarzaniem raz na zawsze ustalonych formuł wiary. Okazało się, że również dogmat odznacza się swoistą otwartością zarówno na przeszłość (dawnych sformułowań nie można całkowicie odrzucić, chociaż zastępuje się je nowymi), jak i przyszłość w oczekiwaniu pełniejszych sformułowań3. Dokonująca się w przekazie wiary nieustanna recepcja Objawienia jest więc „żywym, kierowanym przez Ducha Świętego procesem eklezjalnym, dokonującym się w nauczaniu i całym życiu Kościoła".

\section{JEDYNIE POWTÓRKA Z HISTORII?}

Należy zauważyć, że sama świadomość historycznego rozwoju doktryny wiary również jest efektem historycznego rozwoju. Od czasów średniowiecza kwestia ta koncentrowała się wokól pytania o możliwość pojawienia się nowych articuli fidei, a od końca XVIII i początku XIX wieku rozważana jest pod hasłem rozwoju dogmatów. Punktem wyjścia oraz tłem teologicznej debaty, jaka towarzyszy temu zagadnieniu, jest - od czasów G. W. F. Hegla i romantyzmu - narastająca świadomość historii i historyczności. Zanim bliżej przyjrzymy się tej kwestii, warto cofnąć się wstecz do samych początków chrześcijaństwa.

W przekonaniu św. Pawła istota bycia chrześcijaninem wyraża się w krótkim wyznaniu wiary, mającym formę świadectwa: „Jeżeli więc ustami swoimi wyznasz, że Jezus jest Panem, i w sercu swoim uwierzysz, że Bóg Go wskrzesił z martwych - osiągniesz zbawienie" (Rz ıo, 9).W ten sposób apostoł wskazuje dwa bieguny, między którymi sytuuje się nasza chrześcijańska wiara. Pierwszym z nich jest jej historyczny początek w wydarzeniu Jezusa Chrystusa. Sama osoba ziemskiego Jezusa - Jego

3 Por. W. Hryniewicz, Wiara rodzi się w dialogu, pod redakcją R. M. Rynkowskiego, Kraków 2015, s. 87.

4 W. Kasper, Katholische Kirche. Wesen - Wirklichkeit - Sendung, Freiburg im Br. 2OII, s. 33 .

5 Krótki przegląd tej tematyki zob. W. Kern, F.-J. Niemann, Theologische Erkenntnislehre, Düsseldorf 1981, s. I29-I49 (Leitfaden Theologie 4). 
czyny i słowa, tak jak zostały nam one przekazane w słowie apostolskiego świadectwa oraz utrwalone w kanonie Nowego Testamentu - stanowi punkt wyjścia oraz normę wiary. Na drugim biegunie stoi zmartwychwstały i wywyższony „Pan” (Kyrios), który dzięki posłaniu Ducha Świętego w każdym czasie, również dzisiaj, działa w Kościele i wobec Kościoła. Ewangelia Janowa mówi o tym, że wierny orędziu Jezusa „Duch Prawdy” doprowadzi wspólnotę uczniów „do całej prawdy”i objawi im to, czego „teraz znieść nie mogą” (por. J I6, I2-I5). Przykładem takiego twórczego (i - zgodnie z przekonaniem Kościoła powszechnego - zdziałanego przez Ducha Świętego, a w konsekwencji wiernie kontynuującego autentyczne orędzie Jezusa) rozwoju Jezusowego przepowiadania jest misja do pogan. W Mt Io, 5 ziemski Jezus zabrania uczniom takiej misji, natomiast w Mt 28, I9n zmartwychwstały Pan wręcz ją nakazuje. Ciekawie w tym kontekście przedstawiają się spory dotyczące sposobu życia chrześcijan pochodzenia pogańskiego, jakie toczono wewnątrz pierwotnego Kościoła (zob. Dz I5, I-29; Ga 2, II-I4). Okazuje się, że ich główni uczestnicy, tj. Paweł oraz stojący na czele judeochrześcijańskiej wspólnoty w Jerozolimie „Brat Pański” Jakub, mieli zasadniczo różne zdania co do tego, czy misja wśród pogan, która nie respektuje przepisów Tory, faktycznie odpowiada nauczaniu ziemskiego Jezusa. Historycznie rzecz biorąc, poparcie zyskało stanowisko Pawła (według Dz ıo, I-48; I5, 8-II także Piotra), który - rzecz ciekawa - w swej argumentacji odwoływał się nie do wskazań lub praktyki ziemskiego Jezusa, lecz do doświadczeń duchowych. Powtarzane zwłaszcza w literaturze epistolarnej Nowego Testamentu słowa przestrogi przed „inną Ewangelią” (Ga I, 6-9; por. 2 J ıo) pokazują też, że ukazana w kanonie Nowego Testamentu harmonia między wydarzeniem początku a konkretną aktualizacją Jezusowego nauczania nie zawsze była możliwa .

Stwierdzenie to w jeszcze większym stopniu dotyczy dalszych etapów rozwoju doktryny chrześcijańskiej. Joseph Ratzinger stawia tezę, że historia dogmatu nie zna ani jednego twierdzenia, którego nie byłoby w Piśmie Świętym, a którego istnienie można by z jakimś historycznym prawdopodobieństwem wykazać aż do epoki apostołów?. Dotyczy to również trzech klasycznych przykładów: kanonu Pisma, liczby siedmiu sakramentów oraz chrztu dzieci. Jak wiadomo, Kościół nie miał do

6 Por. W. Klausnitzer, Prymat papieża, „Roczniki Teologiczne” 62 (2015), s. I36n.

7 Por. J. Ratzinger, O nauczaniu II Soboru Watykańskiego. Formutowanie - PrzekazInterpretacja, thum. W. Szymona, Lublin 20I6, s. I43 (Opera Omnia, 7/I). 
dyspozycji pozostawionego przez ostatniego z apostołów gotowego dokumentu informującego, które księgi miałyby razem stanowić $\mathrm{Pi}^{-}$ smo Święte. Dopiero w IV wieku, w procesie zmagań ludzkiej historii i nieustannego wsłuchiwania się w działającego w nim Ducha Świętego, Kościół ustalił kanon pism Nowego Testamentu. Właśnie owo „żywe zmaganie się w Duchu Świętym” - konkluduje Ratzinger - „stanowi proces tradere, czyli wychodzące poza Pismo i jego literę plus Tradycji,

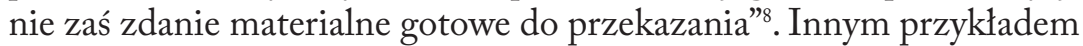
jest ogłoszony przez Piusa xII dogmat Wniebowzięcia Najświętszej Maryi Panny. Można wykazać, że przed V wiekiem o assumptio corporalis Matki Bożej niczego nie wie także Tradycja. Historycznie jest całkowicie pewne, że pierwsze spisane wzmianki na ten temat nie są późniejszą relacją tego, co wcześniej było przekazywane z ust do ust, ale są „nowym poznaniem", które właśnie wtedy dopiero się pojawiło, a potem zaczęły się trwające całe wieki zmagania w dążeniu do zrozumienia tej prawdy, aż w końcu w I950 roku Kościół ogłosił, że było to poznanie w Duchu Świętym, w związku z czym stanowi ono istotną treść Objawienia9. Stąd też Tradycji nie można pojmować jako materialnego przekazywania niezapisanych zdan, lecz jako proces permanentnego rozwoju samego Objawienia. W ten sposób dochodzimy do ważnych i ciągle dyskutowanych kwestii, którymi są rozwój poznania teologicznego oraz możliwość postępu w teologii. Warto w tym kontekście odwołać się do myśli dwóch wielkich teologów średniowiecznych - św. Tomasza z Akwinu oraz św. Bonawentury.

Doctor communis wychodzi z założenia (z którym zgadza się również Bonawentura), że o Bogu nie możemy powiedzieć niczego, co nie jest zawarte (dosłownie lub co do sensu) w Piśmie Świętym ${ }^{\mathrm{ro}}$. Rozwijanie depozytu wiary, które zasadniczo jest możliwe, Tomasz wiąże przyczynowo z rozwojem herezji. Konkretnie oznacza to, że „dogmatyzacje”, czyli rozszerzenie Symbolum, są odpowiedziami na poprzednie błędy i służą ich wykluczeniu. Pojawienie się błędu nakłada na Kościół obowiązek

8 J. Ratzinger, O nauczaniu II Soboru Watykańskiego, dz. cyt., s. I43.

9 Por. J. Ratzinger, O nauczaniu II Soboru Watykańskiego, dz. cyt., s. I45.

Io Thomas de Aquino, Summa theologiae, in: Die deutsche Thomas-Ausgabe: Vol1ständige, ungekürzte deutsch-lateinische Ausgabe der Summa theologica, übers. von Dominikanern u. Benediktinern Deutschlands u. Österreichs, hg. von Heinrich M. Christmann u.a., 36 Bde., Heidelberg-München-Graz ı933ff, I, q. 36, a. 2 ad. r: „[...] de Deo dicere non debemus quod in sacra scriptura non invenitur per verba vel per sensum”. 
sprecyzowania swojej wiary, czego przykładem jest m.in. włączenie do wyznania wiary Filioque. Łatwo zauważyć, że w takiej wizji rozwoju doktryny Kościoła mocno podkreślona jest kontynuacja: „dogmatyzacja” jest niczym innym, jak eksplikacją sensu, która doprowadza do końca to, co było już zawarte w Piśmie Świętym ${ }^{\text {II }}$

Również dla Bonawentury herezja stanowi zewnętrzną okazję do ujawnienia prawdy wiary, która wcześnie istniała implicite, i jako taka była wewnętrzną przyczyną umożliwiającą jej eksplikację ${ }^{\mathrm{I2}}$. Z drugiej strony Doktor Seraficki zauważa, że wraz z dogmatem tworzy się rzeczywiście coś nowego i że jest to uzasadnione, „gdyż Kościół rzymski otrzymał pełnię władzy od księcia apostołów Piotra, z racji której żadna wypowiedź czy zakaz ojców nie może go ograniczać, nie może go uprzedzać w decyzjach czy go do czegoś zobowiązywać”ㄱ. W tej teorii dogmatyzacji podkreślona została idea postępu, która nie unika tezy, że istnieje rzeczywisty proces rozwoju wiary, którego nie zapoczątkował dopiero Chrystus, lecz który zaczyna się już w Starym Testamencie.

Tak oto w osobach Tomasza z Akwinu i Bonawentury uwidaczniają się dwie wizje względnie modele rozwoju dogmatów: model kontynuacji (Tomasz) oraz model postępu (Bonawentura). U ich podstaw znajduje się inne pojęcie historii, które dzieli tych dwóch wielkich teologów XIII wieku. Zdaniem Doktora Serafickiego wnioskowanie teologiczne nie dokonuje się czysto racjonalnie (historycznie bądź spekulatywnie), lecz zakłada nowe objawienie, nową revelatio. W związku z tym historia zbawienia nie jawi mu się jako jednolity ciąg wydarzeń, lecz jako proces, w którym mamy do czynienia z pewnymi „skokami”, a dokładniej ze stopniami historiozbawczymi ${ }^{\text {I4 }}$. Należy przy tym pamiętać, że według Bonawentury objawienie (revelatio) zawiera - zgodnie z przedtomistycznym rozumieniem tego terminu - zarówno moment zewnętrzny, obiektywny, jak i aktualny moment wewnętrzny, podmiotowy. $Z$ tego

II Por. J. Ratzinger, Objawienie - Pismo - Tradycja. Tekst sw. Bonawentury i jego znaczenie dla teologii wspótczesnej, w: J. Ratzinger, Rozumienie objawienia i teologia historii wedtug Bonawentury. Rozprawa habilitacyjna i studia nad Bonawentura, tłum. J. Merecki, Lublin 20I4, s. 622n (Opera Omnia, 2) [dalej: JROo 2].

I2 Por. JRoo 2, s. 623.

I3 Bonaventura, Commentaria in quatuor libros sententiarum Magistri Petri Lombardi, in: Doctoris seraphici S. Bonaventurae Opera omnia, tomus I, Collegium S. Bonaventurae, Rome 1882, Collection: Boston College Library; blc; americana, d. II, q. I c (I 2 I2 b).

I4 Por. JROo 2, s. 624n. 
też powodu „«objawienie» w sensie wewnętrznego zwrócenia się Boga do człowieka musi dokonywać się zawsze na nowo w czasie, w którym obiektywna strona samoobjawienia się Boga dawno została zakończona. W ten sposób może pojawić się idea,że w tym lub innym miejscu historii «objawienie» zyskuje szczególną moc" "ᄁs. Dopiero Tomaszowa empiryczna nauka o poznaniu spowoduje zasadniczy zwrot, polegający na zerwaniu $z$ tak rozumianym terminem revelatio (objawienie zaczyna być coraz bardziej rozumiane intelektualistycznie, jako system prawdziwych twierdzeń poręczonych autorytetem Boga i pozytywnie podanych w Biblii albo przez Magisterium), a w dalszej konsekwencji na sprowadzeniu rozwoju dogmatu do eksplikacji tego, co implicite zawiera się w istniejącym już twierdzeniu doktrynalnym. Ponieważ Objawienie już się zakończyło, argumentowano, rozwój doktryny kościelnej może polegać jedynie na poprawnym interpretowaniu i pojęciowym wyjaśnianiu poszczególnych prawd zawartych od początku w dokumentach Objawienia (w Piśmie i Tradycji). Taka wizja rozwoju doktryny w historii Kościoła była charakterystyczna zwłaszcza dla neoscholastyki przełomu xIx i xx wieku, która swoją metodę uprawiania teologii oparła na logiczno-formalnej dedukcji, wzorowanej na sylogizmie (pojęcie, sąd, wniosek).

\section{TRADYCJA W KONTEKŚCIE HistoRYCZnEGO ROZUMIENIA PRAWDY}

Pierwotna tradycja chrześcijańska łączyła dogmat z żywią wiarą całego Kościoła. Sformułowania doktrynalne pojmowano przede wszystkim $\mathrm{w}$ sensie doksologicznym jako wyznania wiary i uwielbienie Boga, stanowiące integralną część obrzędów liturgicznych. Dlatego uważano, że prawdy wiary, w tym również dogmaty, wykraczają daleko poza aktualne sformułowania językowe. Taka dynamiczna i otwarta koncepcja dogmatu była jeszcze obecna w średniowieczu. Wielcy teologowie tego okresu, tacy jak Albert Wielki, Tomasz z Akwinu czy Bonawentura, zgodnie definiowali „artykuł wiary” jako „percepcję prawdy Bożej, zmierzającej do niej samej" (articulus fidei est perceptio divinae veritatis tendens in ipsam) ${ }^{\mathrm{r}}$.

I5 JROO 2, s. 634 .

I6 Thomas de Aquino, Summa theologiae, dz. cyt., II-II, q. I, a. 6; Albertus Magnus, Super III Sententiarum, in: Albertus Magnus' Opera omnia, vol. 28, ed. A. Borgnet, Paris I894, d. 24, a. 4; Bonaventura, Commentaria in quatuor libros sententiarum Magistri Petri 
W sformułowaniu tym widać wyraźnie świadomość historycznego i eschatologicznego wymiaru dogmatu, wynikającą z niedoskonałości ludzkiego ujmowania prawdy oraz jego odniesienia do ostatecznego celu człowieka. Jako słowo ludzkie, dogmat $\mathrm{z}$ zasady nie jest w stanie wyczerpująco wyrazić i przekazać treści wiary. Wprawdzie nie jest on tworem czysto subiektywnym, jak utrzymywały modernizm i teologia liberalna, odnosi się bowiem do określonych treści zawartych w samym Objawieniu, niemniej jednak rzeczywistość nadprzyrodzona wymyka się wszelkim próbom adekwatnego ujęcia i wyrażenia jej w skończonych pojęciach naszego rozumu. $\mathrm{Na}$ tym też polega podstawowy problem epistemologiczny, z jakim od samego początku boryka się świadoma swych granic teologia. Jürgen Werbick wyraził tę kwestię następująco:

Bóg objawia się w procesie samo-tłumaczenia. [...] Jak można jednak w ogóle pomyśleć, że ludzki język i wyobraźnia są capax infiniti - że mogą zawrzeć w sobie to, co nieskończone - że w procesie przekładu i interpretacji Nieskończony nie zostanie zdegradowany i sprowadzony do poziomu skończoności? W jaki sposób uchronić samo-tłumaczenie Boga na język ludzki przed ludzkim sposobem pojmowania oraz przed przetlumaczeniem Go na to, co wyobrażalne?r7

Podstawę prawdy dogmatu, której nie należy utożsamiać z jej ujęciem językowym ${ }^{18}$, stanowi partycypowanie w prawdzie Objawienia. Jednak w swym roszczeniu do nieomylnego wyrażania prawdy dogmat musi uwzględnić warunki skończonego rozumu i granic ludzkiego poznania oraz poruszać się w obrębie możliwości przekazu ludzkiego języka. Dogmat nie wyraża więc ponadczasowej prawdy w znaczeniu racjonalistycznej metafizyki lub bezpośredniego poznania istoty Boga w doświadczeniu wiary. Jest on raczej następstwem historycznego samudzielania się Boga człowiekowi i jako taki podlega nieustannemu doskonaleniu,

Lombardi, in: Doctoris seraphici S. Bonaventurae Opera omnia, dz. cyt., tomus III, d. 24, a. 3 , q. 2 .

I7 J. Werbick, Den Glauben verantworten. Eine Fundamentaltheologie, Freiburg im Br. 2000 , s. 405 .

I8 Dlatego zdaniem św. Tomasza z Akwinu akt wiary nie odnosi się do formuły wiary, ale do „rzeczy”, którą owa formuła usiłuje wypowiedzieć. Por. Thomas de Aquino, Summa theologiae, dz. cyt., II-II, q. I, a. 2, ad 2: „actus autem credentis non terminatur ad ennuntiabile, sed ad rem". 
pogłębianiu i doprecyzowywaniu. Jak trafnie zauważył Karl Rahner, dogmat jest „wypowiedzią prowadzącą w głąb Misterium”ı i dlatego zawsze już nieskończenie przekroczoną przez samowypowiedzenie się owego Misterium w Jezusie Chrystusie ${ }^{20}$.

Wypowiedź Urzędu Nauczycielskiego Kościoła w sprawie rozwoju dogmatów zawarta jest w deklaracji Mysterium Ecclesiae (I973) ${ }^{21}$. Czytamy w niej, że rozwój dogmatu w historii Kościoła zawsze istniał i również w przyszłości nadal („wciąż na nowo”) będzie miał miejsce. Dogmaty, które zostały sformułowane w kontekście danej epoki historycznej oraz w konkretnym języku, są w sposób oczywisty od tej epoki i tegoż języka zależne, odnoszą się „niekiedy” do aspektów Bożej prawdy i odpowiadają w swojej interpretacji Pisma Świętego i Tradycji na specyficzne pytania,

I9 K. Rahner, Was ist eine dogmatische Aussage?, w: K. Rahner, Schriften zur Theologie, t. 5 , Einsiedeln $1964^{2}$, s. 72 .

20 W tym kontekście Rahner czyni rozróżnienie między prawdą wiary (,istotą rzeczy”) a jej modelem pojęciowym („amalgamatem”). Podczas gdy „istota rzeczy” zawsze zachowuje swoją moc, ,amalgamat” może z czasem okazać się błędny. W takiej sytuacji należy szukać nowych sformułowań, bardziej adekwatnych do „istoty rzeczy”. Nieuwzględnienie tego rodzaju rozróżnienia prowadzi często do odrzucenia samej prawdy wiary, którą błędnie utożsamia się z jej pojęciowym modelem. Por. K. Rahner, Historia dogmatów i teologii z wczoraj na dzis, w: K. Rahner, Pisma wybrane, t. I, tlum. G. Bubel, Kraków 2005, s. I03: „Twierdzenia bowiem, które w określonej epoce nie było w stanie wyrazić tego, co w nim prawdziwe, inaczej niż przy użyciu pewnego określonego modelu pojęciowego itd. («amalgamat»), nie należy określać jako błędnego, gdyż w określonej epoce reprezentowało ono jedyną możliwość wyrażenia tego, co w nim prawdziwe. Ten, kto wypowiedział wtedy to twierdzenie, wypowiedział ówcześnie prawdę”. Przy tym należy pamiętać, „że «dzisiejsze» rozróżnienie pomiędzy właściwą treścią a amalgamatem nie dokonuje się w ten sposób, jakbyśmy obecnie wyrażali właściwą treść w swego rodzaju «chemicznej czystości» dla niej samej, lecz wypowiedź ta także i w tym przypadku jest formułowana w świetle innych modeli pojęciowych, które są uwarunkowane poprzez przynależność do pewnej epoki” (tamże). Inaczej mówiąc, nie tylko prawda rzeczy, ale również prawda objawienia chrześcijańskiego, jest uwarunkowana historycznie. Dlatego proces wchodzenia w tajemnicę Boga musi dokonywać się w świetle ciągle nowych, historycznych sytuacji prawdy (por. tamże, s. Io4).

2I Kongregacja Nauki Wiary, Deklaracja „Mysterium Ecclesiae” o katolickiej doktrynie o Kościele przeciw niektórym wspótczesnym btędom, w: W trosce o petnię wiary-Dokumenty Kongregacji Nauki Wiary 1966-I994, tłum. i oprac. Z. Zimowski, J. Królikowski, Tarnów I997, s. 59-6I (= nr 5). 
których znajomość jest konieczna dla ich właściwej interpretacji. Tym samym rozstrzygająca wypowiedź Urzędu Nauczycielskiego Kościoła nie stanowi jeszcze końca rozwoju dogmatu. Zastosowane przez Magisterium „wypowiedzi” i „formuły” („należycie interpretowane”) pozostają wprawdzie zawsze pomocne dla przekazywania prawdy objawionej; mogą one jednak zostać uzupełnione, a nawet zastąpione bardziej odpowiednimi (bardziej adekwatnymi) wypowiedziami i sformułowaniami, pod tym jednak warunkiem, że znaczenie (sens) dogmatu nie ulegnie przez to zmianie ${ }^{22}$.

Także konstytucja Vaticanum II o objawieniu Bożym mówi o tym, że raz na zawsze zrealizowane Objawienie, które w Jezusie z Nazaretu, będącym Chrystusem, osiągnęło swoją pełnię i kres (por. DV 4), wciąż na nowo musi być rozważane, analizowane i interpretowane w kontekście aktualnej sytuacji, tak, że można mówić niemal o „postępie” „Tradycji Apostolskiej” oraz „wzroście” w „rozumieniu tak rzeczy, jak przekazywanych słów” (,już to dzięki kontemplacji oraz dociekaniu wiernych, którzy je rozważają w sercu swoim [por. Łk 2, I9 i 5I], już też dzięki głębokiemu, doświadczalnemu pojmowaniu spraw duchowych, już znowu dzięki nauczaniu tych, którzy wraz z sukcesją biskupią otrzymali niezawodny charyzmat prawdy") (Dv 8).

\section{MiĘDZY „ARCHEOLOGIZMEM” A „ENTUZJAZMEM”}

W obliczu narastających na tym polu trudności i niejasności, Rahner postulował sformułowanie przekonującej teorii teologicznej, będącej w stanie uniknąć dwóch skrajności: $\mathrm{z}$ jednej strony teologii liberalnej i modernizmu, ,które powołując się na rezultaty historii ducha i dogmatu

22 Kongregacja Nauki Wiary, Deklaracja „Mysterium Ecclesiae” o katolickiej doktrynie o Kościele przeciw niektórym wspótczesnym btędom, nr 5: „Samo natomiast znaczenie formuł dogmatycznych zawsze pozostaje w Kościele prawdziwe i stałe, nawet wtedy, gdy jest głębiej wyjaśniane i pełniej rozumiane. Wierni powinni więc odrzucić opinię, według której: I) formuły dogmatyczne (lub jakiś ich rodzaj) nie mogłyby dokładnie wyrażać prawdy, lecz tylko w jej zamiennych przybliżeniach, które są w jakiś sposób jej zniekształceniami lub podlegają zmianie; 2) wspomniane formuły wyrażają prawdę w sposób nieokreślony, i dlatego należy jej ciągle szukać przy pomocy owych przybliżeń. Kto przyjmowałby taką opinię, nie może uchronić się przed relatywizmem dogmatycznym i zniekształcałby pojęcie nieomylności Kościoła, dotyczącej jednoznacznego nauczania i przyjmowania prawdy”. 
kwestionują tożsamość (niezmienność) dogmatu kościelnego w czasie", z drugiej zaś tradycyjnej katolickiej „apologetyki tejże tożsamości, która dopuszcza jedynie mało znaczące zmiany w obrębie sformułowań słownych" ${ }^{23}$. Ratzinger i Walter Kasper mówią w tym kontekście o dwóch błędnych drogach przekazywania Objawienia ${ }^{24}$. W obydwu przypadkach mamy do czynienia $\mathrm{z}$ brakiem syntezy tożsamości doktryny wiary (w sensie ustanowionej przez Boga i dlatego niezmiennej prawdy) i jej historycznie uwarunkowanej, zależnej od kontekstu i dlatego podlegającej ciągłym zmianom artykulacji. Zamiast tego dochodzi w nich do jednostronnego przeakcentowania jednego bądź drugiego aspektu ${ }^{25}$.

- Według ,archeologizmu”26 jedyną normą dzisiejszego rozumienia wiary i Kościoła jest ich wcześniejsza lub najwcześniejsza forma. „Archeologizm" posługuje się schematem upadku względnie oryginalności, zgodnie z którym to, co czasowo wcześniejsze, już z tego powodu jest również rzeczowo bardziej oryginalne. W xıx wieku była to pozycja „teologicznego klasycyzmu”, charakterystycznego dla myśli katolickiej. Jednym $z$ przedstawicieli tego nurtu był Johann Josef Ignaz von Döllinger ${ }^{27}$. Zdaniem Ratzingera ,archeologizm” (jako jedna $\mathrm{z}$ form

23 K. Rahner, Überlegungen zur Dogmenentwicklung, w: K. Rahner, Schriften zur Theologie, t. 4, Einsiedeln 19675, s. I3.

24 J. Ratzinger, Das Problem der Dogmengeschichte in der Sicht der katholischen Theologie, w: J. Ratzinger, Glaube in Schrift und Tradition. Zur Theologischen Prinzipienlehre, Freiburg im Br. 2016, s. 553-580 (Gesammelte Schriften, 9/I) [dalej: JRGs 9/r]; W. Kasper, Tradition als Erkenntnisprinzip. Systematische Überlegungen zur theologischen Relevanz der Geschichte, w: W. Kasper, Evangelium und Dogma. Grundlegung der Dogmatik, Freiburg im Br. 2015, s. 504 (Gesammelte Schriften, 7) [dalej: wKGs 7]; W. Kasper, Tradition als theologisches Erkenntnisprinzip, w: WKGs 7, s. 536n.

25 Por. W. Klausnitzer, Christliche Offenbarungslehre. Lehrbuch der Fundamentaltheologie für Studierende, Religionslehrer und Religionslehrerinnen, Heiligenkreuz 2016, s. 473n; W. Beinert, Das entschiedene Jein. Über Ursachen und Grundlagen des Fundamentalismus der Gegenwart, „Renovatio“ 5I (I995), s. 43-57. Beinert rozróżnia pozycje „progresywizmu” (łącznie z wariantem ekstremalnym „modernizmu”) i „konserwatyzmu” (z pozycją ekstremalną „fundamentalizmu”).

26 J. Ratzinger, Anthropologische Grundlegung des Begriffs Überlieferung, w: JRGs 9/1, s. 496 .

27 Główny motyw „teologicznego klasycyzmu” obecny jest już w słynnym dziele Wincentego z Lerynu (zm. ok. 450) „Commonitorium”. Współczesny św. Augustynowi mnich i uczony stwierdza mianowicie, że kryterium prawowierności (katolickości) sta- 
fundamentalizmu) wyraża próbę „zakończenia Tradycji w jakimś dowolnym punkcie" ${ }^{28}$ - czy to w trzech pierwszych wiekach chrześcijaństwa (przed tak zwanym zwrotem Konstantyńskim), w siedmiu lub ośmiu soborach ekumenicznych, bądź też w określonej postaci liturgii trydenckiej. Chrześcijaństwo staje się jednak wtedy religią księgi (podobnie jak islam) albo jedną z form antyczno-klasycystycznej religii.

- W ramach stanowiska zwanego „entuzjazmem” głosi się, że współczesna postać doktryny i Kościoła jest właśnie tą chcianą przez Boga. Wyrażenie „entuzjazm” pojawia się już u Marcina Lutra, który odniósł je do Kościoła papieskiego oraz „ruchów przebudzeniowych”. „Entuzjazm” posługuje się schematem ewolucji względnie rozwoju, który historię wiary i dogmatu interpretuje jako organiczny rozwój z początkowego zalążka oraz absolutyzuje ostatnio osiągniętą postać względem postaci ją poprzedzających. W tej perspektywie obecna forma dogmatu i Kościoła stanowi niemal chrześcijańskie „non plus ultra”, a przynajmniej dotąd najdoskonalszą postać chrześcijaństwa. W konsekwencji dalszy postęp może dokonywać się jedynie na drodze doskonalenia tego, co jest, a nie poprzez sięganie do tego, co było. Czyni się to wprawdzie w poczuciu odpowiedzialności względem dzisiejszego sposobu myślenia i wobec współczesnego człowieka, jednak bez względu na diachroniczno-historyczny charakter wiary. Taki sposób podejścia do rozwoju doktryny chrześcijańskiej uwidocznił się m.in. w myśli Hermanna Samuela Reimarusa u progu oświeceniowej krytyki biblijnej w XVIII wieku, którego zamiarem było ukazanie Jezusa historycznego w opozycji do Tradycji kościelno-dogmatycznej (a więc nie poprzez dogmat, lecz wbrew niemu) ${ }^{29}$. „Entuzjazm” w formie dzisiejszej rości sobie pretensje do tego, by na

nowi „to, co wszędzie, co zawsze, w co wszyscy wierzyli” (quod ubique, quod semper, quod ab omnibus creditum est). W myśl tego kryterium postęp w teologii może być jedynie rozwinięciem nauki odziedziczonej po przodkach, a nie zmianą. Zasada ta stanie się głównym argumentem teologów katolickich przeciwko reformatorom w xvı wieku. Co ciekawe, podczas soboru watykańskiego I (1870) grupa katolickich uczonych, skupionych wokół Döllingera, posłużyła się nim przeciwko ogłoszeniu dogmatu o prymacie i nieomylności papieża. Por. W. Klausnitzer, Grundkurs katholische Theologie: Geschichte. Disziplinen. Biografien, Innsbruck 2002, s. I42.

28 J. Ratzinger, Anthropologische Grundlegung des Begriffs Überlieferung, dz. cyt., s. 496.

29 Por. J. Ratzinger, Anthropologische Grundlegung des Begriffs Überlieferung, dz. cyt., s. 485 . 
podstawie bezpośredniego dostępu do Boga lub Ducha Świętego (albo nawet ludzkiego rozumu jako najwyższego autorytetu) wyrazić chrześcijańską wiarę bez odniesienia do Tradycji bądź przy pomocy „wyzutego z Tradycji rozumu" ${ }^{\circ}$.

Podczas gdy „archeologizm” nie traktuje poważnie stałej obecności Ducha Chrystusowego w Kościele, „entuzjazm” ignoruje immanentną historyczność względnie fundamentalne i krytyczno-normatywne odniesienie Kościoła do swego początku. W celu uniknięcia obydwu skrajności Kasper (w nawiązaniu do myśli Rahnera i Ratzingera) proponuje „typologiczno-sakramentalne” rozumienie Tradycji ${ }^{1}$. Odpowiada ono zawartemu w Dei Verbum pojęciu Objawienia, zgodnie z którym „Słowo” (lub „Logos”) Boga na wiele sposobów objawiało się w historii, aż wreszcie w pełni objawiło się w Jezusie z Nazaretu, Słowie Wcielonym. Analogicznie do tego, wyrażona w Objawieniu prawda Boga zamanifestowała się werbalnie w konkretnych punktach historii w sposób quasi sakramentalny (i typologiczny), np. w postaci Pisma Świętego lub konkretnych dogmatów ${ }^{32}$. Dlatego też te artykulacje prawdy Bożej lub Słowa Bożego stanowią do dziś trwały element naszej wiary, pełniąc jednocześnie wobec niej funkcję krytyczną. Wynikające stąd zadanie dla teologii i Urzędu Nauczycielskiego Kościoła polega na tym, aby owe językowe artykulacje oraz wyrażony w nich sens ponownie odnieść do centralnego ośrodka wydarzenia chrześcijańskiego, jakim jest samoudzielenie się Boga człowiekowi w Jezusie Chrystusie 33 . W tym znaczeniu proces przyswajania i realizacji Jezusowego orędzia, a wraz z nim historia chrześcijaństwa, trwa nadal i każda epoka, każda kultura i każde pokolenie ma za zadanie dotrzeć do pogłębionego i lepszego zrozumienia dokonanego w Chrystusie Bożego objawienia, uwzględniając każdorazowy kontekst

30 J. Ratzinger, Anthropologische Grundlegung des Begriffs Überlieferung, dz. cyt., s. 496.

3I W. Kasper, Tradition als Erkenntnisprinzip. Systematische Überlegungen zur theologischen Relevanz der Geschichte, w: WKGS 7, s. 504; W. Kasper, Tradition als theologisches Erkenntnisprinzip, w: wKGs 7, s. 536.

32 W. Kasper, Tradition als theologisches Erkenntnisprinzip, dz. cyt., s. 536: „Typologiczno-sakramentalne rozumienie [Tradycji-K. K.] postrzega pojedyncze świadectwa Tradycji jako typy, modele, znaki, w których każdorazowo uobecnia się jedna Tradycja Jezusa Chrystusa w Duchu Świętym”.

33 Por. K. Rahner, Historia dogmatów i teologii z wczoraj i dzis, dz. cyt., s. I05: „Każda pojedyncza wypowiedź wiary powinna [...] zostać wypowiedziana w sposób koherentny z całością wiary oraz z pierwotnym i jednoczącym centrum rzeczywistości wiary”. 
historyczny. Dopiero takie rozumienie Tradycji pozwala - zgodnie zresztą z założeniami Soboru Watykańskiego II - przezwyciężyć „progresywistyczną" hermeneutykę zerwania i zwrócić się w kierunku hermeneutyki kontynuacji i prawdziwej reformy ${ }^{34}$. Przy tym kontynuacji nie można rozumieć („tradycjonalistycznie”) jako zwykłego powtórzenia albo czysto logicznej względnie organicznej eksplikacji wcześniejszych wypowiedzi. Podobnie też reformy nie można sprowadzać do samej tylko pragmatyki, jako zwykłego, praktycznego zastosowania raz na zawsze ustalonych idei $\mathrm{i}$ ich interpretacji. Widać to zwłaszcza w soborowej interpretacji dawnej, zdefiniowanej na wcześniejszych soborach zasady „extra ecclesiam nulla salus" 35 . Hermeneutykę kontynuacji można też dostrzec w przejściu od Syllabusa (I864), z jego odrzuceniem nowożytnych idei z ideą wolności religijnej włącznie, do dokumentów Gaudium et spes i Dignitatis bumanae (1965), które te właśnie idee przyjęły, choć w sposób krytyczny i konstruktywny. To samo można odnieść do encykliki Piusa xi Mortalium Animos (I928), która odrzuciła ruch ekumeniczny, oraz do soborowego dekretu o ekumenizmie Unitatis redintegratio (1964), który ten właśnie ruch ekumeniczny nazwał impulsem Ducha Świętego. $Z$ całą pewnością we wszystkich tych przypadkach nie można mówić o zerwaniu z przeszłością, lecz o twórczej kontynuacji w duchu odnowy ${ }^{36}$.

Ewangelia - konkluduje Kasper - nie jest czymś, co znamy od zawsze (das Altbekannte), lecz jest rzeczywistością wiecznie nową (das erwige Neue). Dlatego sobór nie chciał Kościoła „oświeconego”, lecz odnowionego duchowo z ducha Ewangelii, znajdującego się na drodze osobistego uświęcenia i reformy. Jan xxıII użył w tym kontekście niełatwego do przetłumaczenia słowa aggiornamento, które często jest nadużywane. Nie oznacza ono prostego dopasowania się do współczesności, lecz uobecnienie w dniu dzisiejszym na nowo tego, co zostało przekazane. Dlatego „odnowa” (Erneuerung) jest czymś innym niż „innowacja” (Neuerung). Ponadto należy pamiętać, że odnowa nie jest efektem naszych wysiłków i starań, lecz dziełem Ducha Świętego, który wszystko nam przypomni ( J I4, 26) i jednocześnie doprowadzi do całej prawdy (J I6, I3). Jego „przypominanie” nie jest zwykłym powtórzeniem, lecz uobecnieniem raz na zawsze przekazanej Ewangelii. Według Ireneusza z Lyonu to

34 Por. W. Kasper, Katholische Kirche. Wesen-Wirklichkeit-Sendung, dz. cyt., s. 34 .

35 Zob. B. Sesboüé, Poza Kósiotem nie ma zbawienia. Historia formuty i problemy interpretacyjne, tłum. A. Kuryś, Poznań 2007.

36 Por. W. Kasper, Katholische Kirche. Wesen-Wirklichkeit-Sendung, dz. cyt., s. 34n. 
Duch Święty sprawia, że przekaz Tradycji zachowuje zawsze młodość i świeżośćç ${ }^{3}$. On też sprawia, że Kościól może kroczyć ku coraz większej otwartości, zachowując własną tożsamość i misję wobec świata ${ }^{38}$.

\section{$* * *$}

W artykule postawiono pytanie o rolę Tradycji w Kościele, a dokładniej o stosunek Tradycji do rozwoju poznania teologicznego. Kościół dość wcześnie uświadomił sobie, że wierność Chrystusowemu objawieniu jest czymś więcej niż mechanicznym powtarzaniem raz na zawsze ustalonych formuł wiary. Również dogmat, będący (jednoznacznie i powszechnie od XVIII wieku) przedmiotem fides divina et catholica, odznacza się swoistą otwartością zarówno na przeszłość (dawnych sformułowań nie można całkowicie odrzucić, chociaż zastępuje się je nowymi), jak i przyszłość w oczekiwaniu pełniejszych sformułowań. W artykule poddano krytyce dwa skrajne ujęcia Tradycji: „archeologizm” i „entuzjazm”. Pierwsze jest próbą zakończenia Tradycji w dowolnym punkcie historii; drugie jest wyrazem przekonania, że współczesna postać doktryny i Kościoła jest właśnie tą chcianą przez Boga. Idąc za wskazówkami Rahnera, Ratzingera i Kaspera zaproponowano typologiczno-sakramentalne rozumienie Tradycji. Pozwala ono - zgodnie z założeniami Soboru Watykańskiego II - przezwyciężyć „progresywistyczną” hermeneutykę zerwania i zwrócić się w kierunku hermeneutyki kontynuacji i prawdziwej reformy. Konkretnie oznacza to, że proces przyswajania i realizacji Jezusowego orędzia, a wraz z nim historia chrześcijaństwa, trwa nadal i każda epoka, każda kultura i każde pokolenie ma za zadanie dotrzeć do pogłębionego i lepszego zrozumienia dokonanego w Chrystusie Bożego objawienia, uwzględniając każdorazowy kontekst historyczny, kulturowy i religijny.

37 Irenaeus, Adversus haereses, III, 4, 2, in: Irenäus von Lyon, Adversus haereses / Gegen die Häresien III: Griechisch / Lateinisch / Deutsch, übersetzt und eingeleitet von Norbert Brox, Freiburg im Br. 1995 (Fontes Christiani, Bd. 8/3).

$3^{8}$ Por. W. Kasper, Katholische Kirche. Wesen - Wirklichkeit-Sendung, dz. cyt., s. 35-37. 


\section{BIBLIOGRAFIA}

Beinert W., Das entschiedene Jein. Über Ursachen und Grundlagen des Fundamentalismus der Gegenwart, „Renovatio“ 5I (I995), s. 43-57.

Cuda J., Wiarygodna antropologia. Hermeneutyczny zarys teologii fundamentalnej, Katowice 2002.

Hryniewicz W., Wiara rodzi się w dialogu, pod red. R. M. Rynkowskiego, Kraków 2015.

Kasper W., Evangelium und Dogma. Grundlegung der Dogmatik, Freiburg im Br. ${ }_{2015}$ (Walter Kasper Gesammelte Schriften, 7).

Kasper W., Katholische Kirche. Wesen - Wirklichkeit - Sendung, Freiburg im Br. 2011.

Kasper W., Tradition als Erkenntnisprinzip. Systematische Überlegungen zur theologischen Relevanz der Geschichte, w: W. Kasper, Evangelium und Dogma. Grundlegung der Dogmatik, Freiburg im Br. 2015, s. 483-507 (Walter Kasper Gesammelte Schriften, 7).

Kasper W., Tradition als theologisches Erkenntnisprinzip, w: W. Kasper, Evangelium und Dogma. Grundlegung der Dogmatik, Freiburg im Br. 2015, s. 508-542 (Walter Kasper Gesammelte Schriften, 7).

Kern W., Niemann F.-J., Theologische Erkenntnislehre, Düsseldorf I98I (Leitfaden Theologie, 4).

Klausnitzer W., Christliche Offenbarungslebre. Lebrbuch der Fundamentaltheologie für Studierende, Religionslehrer und Religionslehrerinnen, Heiligenkreuz 2016.

Klausnitzer W., Grundkurs katholische Theologie: Geschichte. Disziplinen. Biografien, Innsbruck 2002.

Klausnitzer W., Prymat papieża, „Roczniki Teologiczne” 62 (2015), s. I3I-I6o.

Kongregacja Nauki Wiary, Deklaracja „Mysterium Ecclesiae” o katolickiej doktrynie o Kościele przeciw niektórym wspótczesnym btędom, w: W trosce o petnię wiary. Dokumenty Kongregacji Nauki Wiary 1966-1994, tłum. i oprac. Z. Zimowski, J. Królikowski, Tarnów i997, s. 54-64.

Müller G. L., Katholische Dogmatik. Für Studium und Praxis der Theologie, Freiburg im Br. 1996 .

Rahner K., Historia dogmatów i teologii z wczoraj na dzis, w: K. Rahner, Pisma wybrane, t. I, tłum. G. Bubel, Kraków 2005, s. 90-I24.

Rahner K., Überlegungen zur Dogmenentwicklung, w: K. Rahner, Schriften zur Theologie, t. 4, Einsiedeln $1967^{5}$, s. II-50.

Rahner K., Was ist eine dogmatische Aussage?, w: K. Rahner, Schriften zur Theologie, t. 5, Einsiedeln I964 ${ }^{2}$, s. 54-8I. 
Ratzinger J., Glaube in Schrift und Tradition. Zur Theologischen Prinzipienlebre, Freiburg im Br. 2016 (Joseph Ratzinger Gesammelte Schriften, 9/I).

Ratzinger J., Anthropologische Grundlegung des Begriffs Überlieferung, w: J. Ratzinger, Glaube in Schrift und Tradition. Zur Theologischen Prinzipienlehre, Freiburg im Br. 20I6, s. 476-497 (Joseph Ratzinger Gesammelte Schriften, 9/1).

Ratzinger J., O nauczaniu II Soboru Watykańskiego. Formutowanie - Przekaz Interpretacja, tłum. W. Szymona, Lublin 2016 (Opera Omnia, 7/1).

Ratzinger J., Objawienie - Pismo - Tradycja. Tekstsw. Bonawentury i jego znaczenie dla teologii wspótczesnej, w: J. Ratzinger, Rozumienie objawienia i teologia bistorii wedtug Bonawentury. Rozprawa habilitacyjna i studia nad Bonawentura, tłum. J. Merecki, Lublin 20I4 s. 6I9-635 (Opera Omnia, 2).

Ratzinger J., Das Problem der Dogmengeschichte in der Sicht der katholischen Theologie, w J. Ratzinger, Glaube in Schrift und Tradition. Zur Theologischen Prinzipienlebre, Freiburg im Br. 2016, s. 553-580 (Joseph Ratzinger Gesammelte Schriften, 9/I).

Ratzinger J., Rozumienie objawienia i teologia historii wedtug Bonawentury. Rozprawa habilitacyjna i studia nad Bonawentura, tłum. J. Merecki, Lublin 2014 (Opera Omnia, 2).

Sesboüé B., Poza Kościotem nie ma zbawienia. Historia formuty i problemy interpretacyjne, tłum. A. Kuryś, Poznań 2007.

Werbick J., Den Glauben verantworten. Eine Fundamentaltheologie, Freiburg im Br. 2000. 